\title{
Factors relate to the hypercreatininemia event of patients at the risk of metabolic syndrome in Jetis I public health center
}

\section{Faktor-faktor berhubungan dengan kejadian hiperkreatininemia pada pasien berisiko sindrom metabolik di puskesmas Jetis I}

\author{
Akrom$^{* 1,2}$, Endang Darmawan ${ }^{1}$, Nuril Maulida ${ }^{1}$ \\ ${ }^{I}$ Fakultas Farmasi Universitas Ahmad Dahlan Yogyakarta \\ ${ }^{2}$ Pusat informasi dan kajian Obat, Universitas Ahmad Dahlan Yogyakarta \\ Jl. Prof. Dr. Soepomo S.H., Janturan, Yogyakarta
}

Accepted: 17-11-2017

\begin{abstract}
ABSTRAK
Sindroma metabolik (SM) merupakan faktor risiko penyakit ginjal kronik (PGK). Kepatuhan menjalani terapi obat salah satu kunci tercapainya target terapi pada SM. Hiperurisemia $(>7 \mathrm{mg} / \mathrm{dL}$ pada laki-laki \& $>5.4 \mathrm{mg} / \mathrm{dL}$ pada wanita) dan hiperkreatininemia $(>1,3 \mathrm{mg} / \mathrm{dL})$ merupakan tanda defisiensi fungsi ginjal. Defisiensi fungsi ginjal merupakan akibat tekanan darah dan kadar gula darah yang tak terkontrol pada pasien SM. Tujuan penelitian adalah mengetahui gambaran kejadian hiperkreatininemia dan faktor-faktor yang berhubungan dengan kejadian hiperkreatininemia pada pasien berisiko SM rawat jalan di Puskesmas Jetis I, Bantul, Yogyakarta. Penelitian observational analitik dengan desain potong lintang ini dilakukan pada 99 pasien SM rawat jalan di Puskesmas Jetis I yang memenuhi kriteria inklusi dan menyetujui ikut serta dalam penelitian. Kadar ureum dan kreatinin darah ditetapkan secara spektrofotometer 5010. Data demografi, diagnosis dan riwayat pengobatan diambil dari rekam medik. Data tingkat kepatuhan pasien dikumpulkan dengan wawancara. Data karakteristik demografi \& klinik hasil pengamatan disajikan secara deskriptif. Untuk mengetahui nilai hubungan antara jenis kelamin, umur, hiperurisemia dan tingkat kepatuhan dengan kejadian hiperkreatininemia dilakukan analisis bivariat menggunakan chisquare. Berdasarkan hasil penelitian pada pasien rawat jalan yang beresiko mengalami SM di Puskesmas Jetis I Bantul, sebanyak 30,3\% tidak patuh dan $69.7 \%$ patuh terhadap pengobatan yang diberikan. Sebanyak 44,4\% responden mengalami hiperkreatininemia dan $8,1 \%$ responden mengalami hiperurisemia. Terdapat hubungan antaraketidakpatuhan, jenis kelamin dan hiperurisemia dengan kejadian hiperkreatininemia dengan Odds ratio masing-masing adalah 3.8, 0.26 dan $7.1(\mathrm{p}<0.05)$. Berdasarkan data hasil penelitian disimpulkan bahwa ketidakpatuhan, jenis kelamin laki-laki dan hiperurisemia berhubungan dengan kejadian hiperkreatininemia pada pasien berisiko SM.
\end{abstract}

Kata kunci : sindrom metabolik (SM), tingkat kepatuhan, kadar ureum dan kreatinin, penelitian potong lintang, Puskesmas

\footnotetext{
Penulis korespondesi:

Akrom

Departemen Farmakologi dan Farmasi Klinik,Universitas Ahmad Dahlan

Jl. Prof.Dr. H. Soepomo, S.H., Janturan, Yogyakarta

Email:akrom@pharm.uad.ac.id
} 


\begin{abstract}
Metabolic syndrome (MS) is a risk factor for chronic kidney disease (CKD). Adherence to drug therapy is one of the keys to achieving therapeutic targets in MS. Hyperuricemia $(>7 \mathrm{mg} / \mathrm{dL}$ in men $\&>5.4 \mathrm{mg} / \mathrm{dL}$ in women) and hypercreatininemia $(>1.3 \mathrm{mg} / \mathrm{dL})$ is a sign of kidney function deficiency. Kidney function deficiency is the result of uncontrolled blood pressure and blood sugar levels in MS patients. The objective of the study was to know the description of the incidence of hypercreatininemia and factors related to the incidence of hypercreatininemia in outpatient at risk of MS at Jetis Public health center (PHC) I, Bantul, Yogyakarta. The analytical observational research with cross sectional design was performed on 99 MS outpatient at Jetis I Public Health Center (PHC) who fulfilled the inclusion criteria and approved the participation in the study. Blood urea and creatinine levels were determined by spectrophotometer 5010. Demographic, diagnosis and treatment data were colleccted from medical record. Patient adherence data were collected by interview. Patient compliance was measured by a medication compliance questionnaire. Demographic and clinical data are presented descriptively. Bivariate analysis with chisquare was performed to determine the value of the relationship between sex, age, hyperuricemia and adherence to the incidence of hypercreatininemia. About 30.3\% of total of outpatients at risk of MS at Jetis I PHC, Bantul, is non-adherence and 69.7\% is adherence to the treatment. As many as $44.4 \%$ of respondents have hypercreatininemia and $8.1 \%$ of respondents have hyperuricemia. There was a relationship between adherence and female sex with the prevalence of hypercreatininemia with an odds ratio of 3.8, 0.26 and 7.1 respectively. Based on the data of the study concluded that non-adherence, male sex and hyperuricemia are associated with the prevalence of hypercreatininemia in patients at risk of MS in Jetis I PHC.
\end{abstract}

Keywords: metabolic syndrome (MS); adherence level; hypercreatininemia;cross sectional study; Public health center (PHC)

\title{
PENDAHULUAN
}

Pada era berjalannya program jaminan kesehatan nasional (JKN) dari pemerintah, puskesmas merupakan pelayanan lini pertama dalam pencegahan dan penanggulangan penyakit kronik di masyarakat (Rahma et al., 2015). SM merupakan salah satu penyakit kronik degeneratif yang menjadi masalah utama kesehatan masyarakat di dunia, termasuk Indonesia (IDF, 2014; Idris, F., 2014; Bernard et al., 2012). SM merupakan faktor risiko penyakit kronik dan fatal seperti gagal ginjal, strok dan jantung koroner (Lingga, 2012; IDF, 2006; Carr, 2003). Pemberian terapi yang berlangsung lama dengan jumlah obat yang tidak tunggal menyebabkan angka kegagalan terapi pada pasien SM tinggi (Martine et al., 2009; WHO, 2003). Kegagalan terapi pada pasien SM salah satunya adalah akibat ketidakpatuhan pasien dalam menjalani terapi (Siregar, 2006). Ramadhan, M.R., (2014) menyebutkan bahwa tingkat kepatuhan yang tinggi dapat menurunkan tekanan darah pada pasien hipertensi. Wijaya et.al (2015) melaporkan hasil penelitian dengan metode pill count di Puskesmas wilayah Surabaya Timur dimana terdapat $54.35 \%$ pasien diabetes mellitus tidak patuh terhadap pengobatan. Keberhasilan terapi yang ditandai dengan kadar gula darah dan tekanan darah yang terkontrol serta tidak terjadi hiperkreatininemia berhubungan dengan tingkat kepatuhan pasien dalam minum obat. Pasien SM dengan tingkat kepatuhan yang semakin tinggi maka tingkat keberhasilan terapi pasien dalam mengontrol kadar gula darah juga semakin tinggi (Mulyani, 2016; Puspita, 2016).

Gangguan fungsi ginjal yang dicirikan dengan hiperurisemia atau hiperkreatininemia merupakan komplikasi yang sering terjadi pada pasien SM gagal terapi (Neki et al., 2015). SM dicirikan dengan keberadaan dari dua atau lebih dari 4 gejala utama yaitu hipertensi, hiperglikemia, dislipidemia atau obesitas sentral. SM merupakan faktor risiko utama kejadian penyakit ginjal kronik (PGK) (Neki et al., 2015). Insiden penyakit ginjal kronik di kecamatan Blahbatuh Gianyar Bali pada pasien SM mengalami peningkatan dibandingkan pasien tanpa komponen SM. SM sebagai salah satu faktor resiko kejadian penyakit ginjal kronis (Hernaningtyas, 2012). Kadar gula darah tinggi atau tekanan darah tinggi menyebabkan komplikasi mikrovaskuler atau makrovaskuler antara lain defisiensi fungsi 
ginjal atau diabetik nefropati (IDF, 2006). Hiperglikemia yang persisten dan pembentukan HbA1c yang berlebihan dapat menyebabkan dinding pembuluh darah menjadi lemah, rapuh, dan mudah mengalami penyumbatan, terutama pada pembuluh-pembuluh darah kecil (Anonim, 2005). Pemeriksaan kadar kretainin merupakan skrining awal dalam penentuan terjadinya kerusakan fungsi ginjal (Verdiansah, 2016).

Angka kunjungan pasien berisiko SM rawat jalan di Puskesmas Jetis I tinggi. Puskesmas Jetis I sudah memiliki Program Pengelolaan Penyakit Kronis (prolanis) dengan anggota kelompok prolanis yang telah rutin mengadakan pertemuan (Anonim, 2015). Keberhasilan program pencegahan dan pengobatan dini penyakit kronis akan berimplikasi pada peningkatan kualitas hidup dan efisiensi anggaran pengobatan (Rahma et al., 2015; Idris, 2014;). SM merupakan salah satu penyakit kronik yang membutuhkan penanganan jangka panjang dan biaya besar (IDF, 2014). Sampai saat ini penelitian evaluatif untuk mengetahui keberhasilan program pengobatan pasien berisiko SM rawat jalan di Puskesmas Jetis I belum dilakukan, terutama yang berkaitan dengan pencegahan kejadian gangguan fungsi ginjal dan faktor-faktor yang berkaitan dalam pencegahan kejadian gangguan fungsi ginjal. Hubungan kejadian hiperkreatininemia dengan tingkat kepatuhan berobat pasien berisiko SM rawat jalan di Puskesmas Jetis I belum diketahui. Penelitian ini untuk mengetahui kejadian hiperkreatininemia dan hubungan tingkat kepatuhan berobat, jenis kelamin dan hiperurisemia dengan kejadian hiperkreatininemia pada pasien berisiko SM rawat jalan di Puskesmas Jetis I, Bantul, DIY.

\section{METODE PENELITIAN}

Jenis penelitian ini adalah observational analitik dengan desain potong lintang. Penelitian ini bertujuan untuk mengetahui gambaran kadar ureum/kreatinin, tingkat kepatuhan dan faktor-faktor yang berhubungan dengan hiperkreatininemia pada pasien berrisiko sindrom metabolik rawat jalan Puskesmas Jetis I Bantul Yogyakarta. Penelitian dilakukan pada bulan September-Desember 2016.

\section{Alat dan Bahan}

Subjek penelitian ini adalah pasien rawat jalan yang berisiko mengalami SM dengan terapi standar atau rutin di Puskesmas Jetis I Bantul, Yogyakarta. Jumlah sampel minimal dihitung dengan menggunakan software openepi (www.openepi.com). Berdasarkan uji pendahuluan diketahui bahwa rerata kadar kreatinin serum sampel pasien berisiko SM di Puskesmas Jetis I adalah $1.28 \pm 0.58 \mathrm{mg} / \mathrm{dL}$, dengan asumsi bahwa rerata kadar kreatinin serum pada penelitian adalah $0.95 \pm 0.49 \mathrm{mg} / \mathrm{dL}$, dengan tingkat kepercayaan 95\% dan power 80\% maka dibutuhkan sampel minimal 86 subjek.

Kriteria Inklusi subjek penelitian adalah pasien yang didiagnosis diabates mellitus (DM) atau hipertensi atau dislipidemia oleh dokter puskesmas, berumur $>18$ tahun dan bersedia mengikuti penelitian ini dengan menandatangani inform concern. Kriteria eklusi subjek penelitian adalah riwayat penyakit ginjal kronik, riwayat kanker, menjalani terapi hipertiroid, ulkus diabetik, dan TBC paru aktif.

Alat yang digunakan dalam penelitian adalah tensimeter untuk mengukur tekanan darah, timbangan dan meteran untuk mengukur berat dan tinggi badan serta form pengambilan data untuk menyalin data karakteristik demografi dan klinik subjek dari rekam medik. Kuesioner untuk mengetahui tingkat kepatuhan merupakan modifikasi kuesioner dari Alvian et al.(2014) dan digunakan untuk panduan wawancara serta mengukur tingkat kepatuhan. Pengukuran kadar ureum, kadar kreatinin dan kadar gula darah dilakukan dengan alat spektrofotometri. Data diagnosis dan riwayat pengobatan diperoleh dari rekam medik. Lembar inform consent dan protokol penelitian telah dikaji dan disahkan oleh komite etik penelitihan kesehatan FKIK UMY (no. 279/EP-FKIK UMY/VIII/2016).

\section{Prosedur Penelitian}

Calon subjek yang sesuai dengan kriteria inklusi dibuat dihubungi satu persatu untuk diminta kesediaannya menjadi subjek penelitian. Calon subjek yang menyatakan bersedia kemudian dijelaskan tentang tujuan, manfaat dan konsekuensi sebagai responden. Calon subjek yang dengan suka rela menyatakan kesediaanya mengikuti penelitian setelah mendapatkan penjelasan kemudian diminta menandatangani lembar persetujuan. Pasien SM yang telah mengisi inform consent kemudian 
dilakukan pemeriksaan klinis oleh dokter puskesmas. Pemeriksaan klinis pasien dilakukan di Puskesmas Jetis I Bantul, Yogyakarta. Sebanyak 99 Pasien berisiko SM yang telah memenuhi kriteria inklusi direkrut sebagai relawan.

Pemeriksaan kadar ureum dan kreatinin darah dilakukan dengan prosedur ringkas berikut: darah tepi diambil dari vena cubiti oleh tenaga analis yang sudah terlatih dengan prosedur sebagai mana tertera dalam protokol yang telah direview komite etik penelitian Universitas Muhammadiyah Yogyakarta. Darah yang sudah terkumpul kemudian dilakukan pemeriksaan kadar gula darah sewaktu, kadar ureum dan kreatinin dengan alat spektrofotometri 5010. Berdasarkan kadar ureum dan kreatinin kemudian status subjek dikategorisasi menjadi hiperurisemia (ya atau tidak) serta hiperkreatininemia (ya atau tidak). Nilai cutt of point untuk menentukan status hiperuremia adalah kadar ureum $>50$ $\mathrm{mg} / \mathrm{dL}$. Nilai cutt of point untuk kejadian hiperkreatininemia adalah kadar kreatinin darah $>1.4$ $\mathrm{mg} / \mathrm{dL}$. Nilai cutt of point untuk kejadian hiperglikemia adalah kadar gula darah sewaktu $>140 \mathrm{mg} / \mathrm{dL}$ (Kee et al., 2007). Tingkat kepatuhan pasien diukur dengan kuesioner kepatuhan sebagaimana yang digunakan Alvian et al.(2014). sudah dijelaskan diwal. Alvian et al.(2014) telah memodifikasi kuesioner Morisky Medication Adherence Scale (MMAS) (Morisky et al., 2008) yang telah diuji validitas dan digunakan mengukur kepatuhan minum obat penderita hipertensi. Skor hasil pengukuran kepatuhan kemudian diklasifikasikan menjadi patuh atau tidak patuh. Tekanan darah diukur oleh petugas puskesmas dengan menggunakan tensimeter digital yang sudah dikaliberasi. Tinggi dan berat badan juga diukur oleh petugas puskesmas yang sudah terlatih.

\section{Analisis Data}

Data karakteristik demografi (umur, jenis kelamin, pendidikan dan pekerjaan) dan klinik (diagnosis dan riwayat pengobatan) disajikan secara deskriptif. Tingkat kepatuhan disajikan secara deskriptif dalam bentuk kategori tidak patuh atau cukup-patuh. Data kadar gula darah sewaktu, tekanan darah, tinggi badan, berat badan, BMI, kadar ureum dan kreatinin dinyatakan sebagai rerata disertai dengan nilai deviasi standar. Data kadar ureum dan kadar kreatinin responden kemudian dilakukan kategorisasi menjadi hiperurisemia (ya/tidak) dan hiperkreatininemia (ya/tidak). Dilakukan analisis bivariat dengan chi square untuk menentukan hubungan antara kadar ureum atau kreatinin darah normal atau tidak normal (hiperurisemia/hiperkreatininemia) dan dilakukan uji asosiasi dengan chi square untuk mengidentifikasi faktor-faktor yang berhubungan dengan kejadian hiperkreatininemia pada pasien berisiko SM.

\section{HASIL DAN PEMBAHASAN \\ Karakteristik demografi responden}

Tabel I menggambarkan karakteristik demografi pasien. Dari Tabel I dapat diketahui bahwa jumlah pasien perempuan lebih banyak dari pasien pria (76.8\% v.s. $23.2 \%)$. Dari data kelompok usia menunjukkan bahwa subjek penelitan yang berusia antara 56-65 tahun adalah yang terbanyak (38.4\%), diikuti kelompok usia 46-55 tahun (31.3\%) selanjutnya kelompok usia 36-45 tahun (15.2\%) dan kelompok usia $>65$ tahun (15.2\%). Sebagian besar subjek adalah berpendidikan rendah (68.7\%) dan sebanyak 31 orang $(31.3 \%)$ berpendidikan tinggi. Sesuai dengan jenjang pendidikan maka sebagian besar subjek bermata pencaharian sebagai swasta yaitu wiraswasta sebanyak 13 orang (13.1\%), petani 12 orang (12.1\%), buruh sebanyak 16 orang (16.2\%),swasta sebanyak 5 orang (5.1\%), nelayan sebanyak 5 orang $(5.1 \%)$, tidak bekerja sebanyak 27 orang (27.3\%), lain-lain sebanyak 17 orang (17.2\%), dan sebagian kecil sebagai pegawai negeri sipil (PNS) sebanyak 4 orang (4\%). 
Tabel I. Karakteristik demografi pasien berisiko SM rawat jalan di Puskesmas Jetis I Bantul tahun 2016

\begin{tabular}{lcl}
\hline $\begin{array}{c}\text { Karakteristik demografi } \\
\text { pasien }\end{array}$ & Jumlah & Persentase \\
\hline $\begin{array}{l}\text { Jenis Kelamin : } \\
\text { Laki-laki }\end{array}$ & 23 & $23.2 \%$ \\
Perempuan & 76 & $76.8 \%$ \\
Usia (tahun) & & \\
36-45 tahun & 15 & $15.2 \%$ \\
46-55 tahun & 31 & $31.3 \%$ \\
56-65 tahun & 38 & $38.4 \%$ \\
>65 tahun & 15 & $15.2 \%$ \\
Kelompok Pendidikan & & \\
Pendidikan Rendah & 68 & $68.7 \%$ \\
Pendidikan Tinggi & 31 & $31.3 \%$ \\
Jenis pekerjaan & & \\
Pegawai negeri sipil & 4 & $4 \%$ \\
Wiraswasta & 13 & $13.1 \%$ \\
Petani & 12 & $12.1 \%$ \\
Swasta & 5 & $5.1 \%$ \\
Buruh & 16 & $16.2 \%$ \\
Nelayan & 5 & $5.1 \%$ \\
Tidak bekerja & 27 & $27.3 \%$ \\
Lain-lain & 17 & $17.3 \%$ \\
\hline
\end{tabular}

Berdasarkan data karakteristik tersebut dapat disimpulkan bahwa subjek penelitian perempuan dengan usia antara 56-65 tahun yang lebih banyak berisiko SM. Kondisi ini sesuai dengan hasil penelitian sebelumnya yang dilakukan oleh Bantas et al., (2012) menyebutkan bahwa prevalensi SM lebih tinggi pada wanita sebesar $21.3 \%$ dibandingkan pria sebesar $12.9 \%$. selain itu, pada wanita dengan usia $>50$ tahun terjadi peningkatan resiko SM dibandingkan pria dengan kelompok umur yang sama (Bantas et al., 2012). Perubahan siklus menopause pada wanita dikaitkan dengan peningkatan komponen SM seperti obesitas, hipertensi, perubahan dari profil lipid, dan hiperinsulinemia (Carr, 2003). Sebagian besar subjek penelitian ini berpendidikan rendah (68.7\%) dan tidak bekerja (27.3\%) yang tentu saja kondisi_sosial ekonomi tersebut berimplikasi pada kemampuan berobat dan ketercapaian parameter klinik, namun hal tersebut teratasi dengan adanya program JKN dari pemerintah (Idris, F., 2014).

\section{Diagnosis dan jenis pengobatan}

SM adalah suatu kumpulan penyimpangan fungsi tubuh yang berupa obesitas sentral, tekanan darah tinggi, dislipidemia, gangguan resistensi insulin atau DM (Codario, 2013; IDF, 2006). Seorang berisiko SM yang dijadikan subjek pada penelitian ini paling tidak memiliki satu jenis diagnosis klinis SM. Jenis diagnosis dan terapi obat pasien berisiko SM yang menjadi subjek penelitian disajikan pada Tabel II. 
Tabel II. Karakteristik klinik dan Jenis terapi obat yang diresepkan oleh dokter pada pasien berisiko SM di Puskesmas Jetis I Bantul, Yogyakarta

\begin{tabular}{|c|c|}
\hline Diagnosis dan jenis terapi & $\mathbf{N}($ Persentase $)$ \\
\hline \multicolumn{2}{|l|}{ Diabetes mellitus+hipertensi+dislipidemia } \\
\hline 1 obat diabetes +1 obat hipertensi +1 obat dislipidemi & $3(3 \%)$ \\
\hline Sub total & $3(3 \%)$ \\
\hline \multicolumn{2}{|l|}{ Diabetes mellitus + Hipertensi: } \\
\hline 1 obat diabetes +1 obat hipertensi & $29(29.3 \%)$ \\
\hline 2 obat diabetes +1 obat Hipertensi & $18(18.2 \%)$ \\
\hline 1 obat diabetes +2 obat hipertensi & $2(2 \%)$ \\
\hline 2 obat diabetes +2 obat hipertensi & $2(2 \%)$ \\
\hline Sub total & $51(51,5 \%)$ \\
\hline \multicolumn{2}{|l|}{ Diabetes mellitus \& dislipidemia: } \\
\hline 1 obat diabetes +2 obat dislipidemi & $2(2 \%)$ \\
\hline 2 obat diabetes +1 obat dislipidemi & $2(2 \%)$ \\
\hline Sub total & $4(4 \%)$ \\
\hline \multicolumn{2}{|l|}{ Diabetes mellitus: } \\
\hline 1 obat diabetes & $19(19.2 \%)$ \\
\hline 2 obat diabetes & $19(19.2 \%)$ \\
\hline 3 obat diabetes & $1(1,2 \%)$ \\
\hline Sub total & $39(39,6 \%)$ \\
\hline \multicolumn{2}{|l|}{ Hipertensi : } \\
\hline 1 obat hipertensi & $1(1 \%)$ \\
\hline Sub total & $1(1 \%)$ \\
\hline \multicolumn{2}{|l|}{ Dislipidemia } \\
\hline 1 obat dislipidemi & $1(1 \%)$ \\
\hline Sub total & $1(1 \%)$ \\
\hline Total & $99(100 \%)$ \\
\hline
\end{tabular}

Dari Tabel II dapat diketahui bahwa sebagian besar responden menderita lebih dari satu penyakit dan mendapatkan lebih dari satu obat rutin, baik obat untuk mengontrol tekanan darah dan atau obat penurun gula darah dan atau obat antidislipidemik. Dari data hasil penelitian ini dapat diketahui bahwa sebagian besar responden adalah penderita DM dan hipertensi yang mendapatkan obat kombinasi antara obat penurun tekanan darah dan obat penurun gula darah $(51,5 \%)$. Responden penderita DM sejumlah 39 pasien $(39,6 \%)$ dengan 19 pasien mendapatkan terapi obat antidiabetes tunggal, 19 pasien mendapatkan terapi obat antidiabetes kombinasi dan satu pasien mendapatkantiga obat antidiabetes. Subjek penderita DM dan dislipidemia sejumlah 4 pasien (4\%), sisanya adalah responden dengan sakit hipertensi atau dislipidemia dengan terapi sesuai dengan indikasi. Hasil penelitian ini sesuai dengan hasil penelitian sebelumnya bahwa sebagian besar penderita SM menderita kombinasi DM dengan hipertensi atau DM dengan dislipidemia atau hipertensi dengan dislipidemi (IDF, 2014;Bernard, 2012).

\section{Kepatuhan pasien}

Tingkat kepatuhan pasien dinilai dengan kuesioner kepatuhan MMAS yang telah dimodifikasi sebagaimana yang digunakan oleh Alvian (2014). Tingkat kepatuhan sangat berperan penting dalam keberhasilan suatu terapi dan mencegah terjadinya komplikasi. Proporsi responden berdasarkan tingkat kepatuhan disajikan pada Tabel III. 
Tabe III. Kategori kepatuhan pasien berisiko SM di Puskesmas Jetis I, Bantul terhadap terapi tunggal ataupun kombinasi pasien beresiko sindrom redictor

\begin{tabular}{lcl}
\hline Kategori Kepatuhan & Jumlah & Persentase \\
\hline Tidak Patuh & 30 & 30.3 \\
Cukup patuh - Patuh & 69 & 69.7 \\
Total & 99 & 100 \\
\hline
\end{tabular}

Berdasarkan data pada Tabel III, angka kejadian ketidak patuhan responden tergolong tinggi yaitu 30,3\%. Hasil penelitian ini sejalan dengan hasil-hasil penelitian sebelumnya (Crame et al., 2008). Keberhasilan terapihiperglikemi maupun tekanan darah tinggi sangat berhubungan dengan tingkat kepatuhan pasien dalam minum obat, semakin tinggi tingkat kepatuhan pasien minum obat maka keberhasilan terapi pasien dalam mengontrol kadar gula darah dan hipertensi juga semakin tinggi (Mulyani, 2016 ; Ramadhan, 2014). Selain itu, keberhasilan terapi yang rendah dapat menyebabkan berbagai komplikasi, misalnya saja pasien diabetes mellitus dengan pengendalian kadar gula darah yang kurang ketat maka dapat menyebabkan komplikasi mikrovaskular yaitu berupa nefropati atau hipertensi yang tidak terkontrol dapat memicu komplikasi gagal ginjal (Anonim, 2005 dan 2006).

\section{Tekanan darah, kadar gula darah sewaktu, kadar Ureum dan kreatinin responden}

Pemeriksaan kadar ureum dan kreatinin merupakan_redictor dalam penentuan terjadinya kerusakan fungsi ginjal (Verdiansah, 2016). Hasil pemeriksaan kondisi klinis pasien berisiko SM di Pskesmas Jetis I Bantul disajikan pada Tabel IV.

Tabel IV. Tekanan darah, BMI, kadar glukosa darah, kadar ureum dan kadar kreatinin pasien berisiko SM rawat jalan di Puskesmas Jetis I, Bantul, DIY

\begin{tabular}{cccc}
\hline Kondisi klinis & Laki - laki & Perempuan & Total \\
\hline TDS (mmHg) & $146.43 \pm 17.17$ & $141.46 \pm 17.12$ & $142.62 \pm 17.17$ \\
TDD (mmHg) & $80.09 \pm 8.10$ & $80.57 \pm 8.74$ & $80.45 \pm 8.56$ \\
BB (Kg) & $62.95 \pm 12.65$ & $54.09 \pm 9.84$ & $56.15 \pm 11.14$ \\
TB (cm) & $160.65 \pm 7.13$ & $149.68 \pm 4.78$ & $152.23 \pm 7.11$ \\
BMI & $24.26 \pm 3.91$ & $24.12 \pm 4.13$ & $24.15 \pm 4.06$ \\
Glukosa Serum (mg/dL) & $234.70 \pm 119.77$ & $264.89 \pm 117.04$ & $257.88 \pm 117.76$ \\
Ureum (mg/dL) & $30.43 \pm 8.63$ & $31.53 \pm 12.43$ & $31.27 \pm 11.62$ \\
kreatinin (mg/dL) & $1.37 \pm 0.29$ & $1.26 \pm 0.34$ & $1.28 \pm 0.33$ \\
\hline
\end{tabular}

Data hasil penelitian menunjukkan bahwa rerata tekanan darah sistolik, rerata tekanan darah diastolik dan rerata kadar glukosa serum pasien berisiko SM belum mencapai target terapi. Rerata kadar kreatinin serum pada pasien laki-laki belum mencapai target terapi sedangkan pada pasien perempuan sudah sesuai dengan target terapi. Berdasarkan panduan klinis untuk pasien SM, target terapi kadar gula darah sewaktu (GDS) adalah kurang $140 \mathrm{mg} / \mathrm{dL}$, kadar ureum $\leq 50 \mathrm{mg} / \mathrm{dL}$ dan kadar kreatinin $\leq 1,4 \mathrm{mg} / \mathrm{dL}$. Target terapi tekanan darah sistolik (TDS) adalah $<140 \mathrm{mmHg}$ dan tekanan darah sistolik (TDS) $<80 \mathrm{mmHg}$ (Kee, 2007; IDF, 2006). 
Berdasarkan data kadar ureum dan kreatinin kemudian dilakukan kategorisasi menjadi 2 kategori normal atau tak normal (hiperurisemia atau hiperkreatininemia). Proporsi responden berdasarkan kategori kadar ureum/kreatinin normal/tidak normal disajikan pada Tabel V.

Tabel V. Kejadian hiperglikemia, hiperuresimea dan hiperkretininemia pada pasien berisiko SM di Puskesmas Jetis I, Bantul, DIY

\begin{tabular}{lcc}
\hline Karakteristik klinik & Jumlah & Persentase \\
\hline Status hiperurisemia & & \\
$\quad$ Normal & 91 & $91.9 \%$ \\
$\quad$ Hiperurisemia & 8 & $8.1 \%$ \\
Status hiperkreatininemia & & \\
$\quad$ Normal & 55 & $55.6 \%$ \\
$\quad$ Hiperkreatininemia & 44 & $44.4 \%$ \\
Total & 99 & $100 \%$ \\
\hline
\end{tabular}

Berdasarkan data pada Tabel V diketahui bahwa sebagian besar subjek $(91,9 \%)$ memiliki kadar ureum normal, 8 subjek $(8,1 \%)$ memiliki kadar ureum tidak normal. Sebanyak 55 subjek $(55,6 \%)$ memiliki kadar kreatinin normal dan 44 subyek $(44,4 \%)$ memiliki kadar kreatinin darah abnormal. Pada penelitian ini diketahun bahwa kadar kreatinin serum subyek lebih banyak yang mengalami abnormalitas jika dibandingkan dengan kadar ureum. Tingginya kadar kreatinin serum merupakan salah satu tanda penurunan fungsi ekskresi dari ginjal akibat nefropati. Nefropati diabetika merupakan salah satu komplikasi paling sering terjadi pada pasien diabetes mellitus. Salah satu faktor yang berperan dalam proses terjadinya komplikasi nefropati adalah ketidakpatuhan pasien (Putri, 2015).

\section{Faktor - faktor yang berhubungan dengan kejadian hiperkreatininemia pada pasien SM}

Pada pasien SM perubahan kadar ureum dan kratinin serum merupakan suatu indikator terjadinya kerusakan fungsi ginjal (Kee, 2007). Jenis kelamin, status pendidikan dan kepatuhan pasien diduga berkaitan dengan kejadian hiperkreatininemia. Hasil penilaian hubungan antara faktor jenis kelamin, status pendidikan dan status kepatuhan dengan kejadian hiperkreatininemia disajikan pada Tabel VI.

Tabel VI. Hubungan jenis kelamin, status tingkat pendidikan dan status kepatuhan dengan terhindar dari kejadian hiperkreatininemia pada pasien SM di Puskesmas Jetis I

\begin{tabular}{lcccc}
\hline \multicolumn{1}{c}{ Karakteristik } & Status hiperkreatininemia & OR (CI95\%) & P \\
& Tidak & Ya & & \\
\hline Jenis kelamin (laki-laki/wanita) & $7 / 48$ & $16 / 28$ & $0.26(0.09-0.70)$ & 0.01 \\
Status tingkat pendidikan rendah(ya/tidak) & $38 / 17$ & $31 / 13$ & $0.94(0.4-2.22)$ & 0.53 \\
Status kepatuhan (ya/tidak) & $23 / 32$ & $7 / 37$ & $3.8(1.44-10.02)$ & 0.01 \\
Status hiperurisemia (tidak/ya) & $69 / 3$ & $13 / 4$ & $7.1(1.4-35.4)$ & 0.02 \\
\hline
\end{tabular}

Berdasarkan data pada Tabel IV maka dapat diketahui bahwa faktor jenis kelamin dan kepatuhan berhubungan dengan kadar kreatinin darah pasien SM di Puskesmas Jetis I Bantul $(\mathrm{p}<0.05)$. Status pendidikan tidak berhubungan dengan kejadian abnormalitas kadar kreatinin (hiperkreatininemia). Penderita SM laki-laki memiliki OR $=0.26$ (CI:0.09 - 0.70; p<0.05) untuk memiliki kadar kreatinin darah normal. Pasien berisiko SM yang patuh memiliki OR $=3.8$ (CI95\%:1.44 - 10.02;p<0.05) untuk memiliki kadar kreatinin normal dan pasien berisiko SM dengan hiperurisemia berhubungan dengan kejadian hiperkreatininemia dengan $\mathrm{OR}=7.1 \quad(\mathrm{p}<0.05)$. Hasil penelitian ini sesuai dengan penelitian sebelumnya yang menunjukkan bahwa pasien wanita cenderung memiliki kepatuhan yang lebih baik jika dibandingkan dengan pasien laki-laki sehingga 
kejadian hiperkreatininemia pada pasien perempuan lebih rendah. Sedangkan pada penelitian yang lain juga menyebutkan bahwa pasien diabetes mellitus yang tidak patuh berobat berisiko meningkatkan kemunculan komplikasi kronik sebesar 3.27 kali dibandingkan dengan pasien diabetes mellitus yang patuh berobat (Sujatmiko et al., 2011). Menurut WHO (2003), pada pasien SM tidak hanya kepatuhan berobat saja yang dapat mempengaruhi kejadian penururnan fungsi ginjal namun faktor genetik, lingkungan dan gaya haidup juga terlibat (Morisky et al., 2008). Ada beberapa faktor lain yang harus diperhatikan guna mencapai hasil terapi yang maksimal, seperti pengaturan diet sesuai anjuran dokter, melakukan olahraga yang teratur dan menghindari rokok, adalah bentuk-bentuk perilaku berobat bagi penderita penyakit kronik yang harus dibiasakan (Sudjatmiko et al., 2011). Sehingga, angka keterjadian komplikasi baik mikrovaskuler ataupun makrovaskuler pada penderita SM berkurang. Keterlibatan farmasis dalam mewujudkan ketercapaian target terapi pada pasien dengan pengobatan jangka panjang terbukti efektif (Olenak et al., 2010; Touchette, 2010).

SM merupakan faktor penduga kejadian penyakit ginjal kronik (Hernaningtyas, 2012). Peningkatan tekanan darah, penumpukan lemak perut, keseimbangan lemak darah terganggu merupakan deretan gejala akibat resistensi insulin. SM yang terjadi ketika resitensi insulin berkolaborasi dengan lemak dan tekanan darah yang tinggi dapat menyebabkan terjadinya komplikasi pada diabetes mellitus berupa nefropati diabetika (Codario, 2013; Lingga, 2012; Martinez et al., 2008). Beberapa faktor etiologi timbulnya diabetik nefropatiadalah hiperglikemia, faktor genetis, merokok, kelainan hemodinamik (peningkatan aliran darah ginjal dan LFG, peningkatan tekanan intraglomerulus dan hipertensi sitemik), gangguan pompa ion (peningkatan $\mathrm{Na}+-\mathrm{H}+$ pump dan penurunan $\mathrm{Ca} 2+$-ATPase pump), dyslipidemia (hiperkolesterolemia dan hipertrigliseridemia) serta aktivasi protein kinase-C (Putri, R.I., 2015; Cheung et al., 2011). Kepatuhan pasien SM terhadap terapi obat dan perilaku berobat merupakan salah satu kunci tercapainya kadar gula darah, tekanan darah dan lemak tubuh yang terkontrol (Mulyani, 2016; Puspita, 2016; Olenak et al., 2010).

\section{KESIMPULAN}

Berdasarkan hasil penelitian ini dapat disimpulkan bahwa kepatuhan, jenis kelamin laki-laki dan hiperuresimea berhubungan dengan kejadian hiperkreatininemia pada pasien berisiko SM rawat jalan di Puskesmas Jetis I, Bantul.

\section{UCAPAN TERIMAKASIH}

Ucapan terima kasih disampaikan kepada Kepala Puskesmas Jetis I dan staf yang telah memberikan fasilitas tempat dan sarana laboratorium. Ucapan terima kasih juga diucapkan kepada seluruh responden yang telah bersedia menjadi subjek penelitian.

\section{DAFTAR PUSTAKA}

Alfian, R., Akrom, E.Darmawan, 2014. Giving oral counseling by phrmacist improve quality of life of hypertensive patients in rural private hospital in Bantul District Yogyakarta, Proceeding International Conference on restorative Justice, 4 Januari 2014, Yogyakarta, 35 - 41.

Anonim. 2015. Profil Puskesmas Jetis 1 Tahun 2015. Puskesmas Jetis 1 Bantul : Yogyakarta.

Anonim. 2005. Pharmaceutical care untuk penyakit diabetes mellitus. Bina Farmasi Komunitas dan Klinik,: Depkes RI, Jakarta, 3-20.

Anonim. 2006. Pharmaceutical care untuk penyakit hipertensi. Bina Farmasi Komunitas dan Klinik,: Depkes RI, Jakarta, 21-43.

Bantas, K., Yosef, H.K., Moelyono, B., 2012. Perbedaan Gender pada Kejadian Sindrom Metabolik pada Penduduk Perkotaan di Indonesia. Jurnal Kesehatan Masyarakat Nasional, 7(5), 3-8.

Bernard, M.Y., Cheung \& Chao Li. 2012. Diabetes and Hypertension: Is There a Common Metabolic Pathway? Curr Atheroscler Rep 14:160-166.

Carr, M.C., 2003. The emergene of metabolic syndrome with menopause. The journal of clinical Endocrinology and Metabolism. 88, 2404-11. 
Cheung CY, Tso AW, Cheung BM, et al. 2011. Genetic variants associated with persistent central obesity and the metabolic syndrome in a 12-year longitudinal study. Eur $J$ Endocrinol,164(3):381-8.

Codario, ronald a. md, facp. 2011. Type 2 diabetes, pre-diabetes, and the metabolic syndrome, Second Edition Springer Science+Business Media, LLC, 32-44.

Crame J. A. r,1 A' . Benedict, N. Muszbek, A. Keskinaslan, Z. M. Khan. 2008. The significance of compliance and persistence in the treatment of diabetes, hypertension and dyslipidaemia: a review. Int J Clin Pract, 62 (1): 76-87.

Idris, F.,2014. Pengintegrasian Program Preventif Penyakit Diabetes Melitus Tipe 2 PT Askes (Persero) ke Badan Penyelenggara Jaminan Sosial Kesehatan (BPJS Kesehatan), J Indon Med Assoc, 64(3), $12-17$.

Hernaningtyas. 2012. Hipertensi, Obesitas sentral, dan Diabetes Mellitus (komponen sindrom metabolik) sebagai predictor kejadian penyakit ginjal kronik : studi kohort retrospektif pada penduduk Kecamatan Blahbatuh Gianyar Bali. Tesis. Program Pascasarjana Universitas Udayana Denpasar: Bali.

International Diabetes Federation, 2006, The IDF Concencus Worldwide Definition of the Metabolic Syndrome.

International Diabetes Federation, 2014. Diabetes Atlas. 6th edition. Brussels, Belgium: International Diabetes Federation; 2014.

Kee, J. L.F., 2007, Pedoman Pemeriksaan Laboraturium \& Diagnostik. Edisi 6. Jakarta : EGC.

Lingga, L., 2012. Program Anti-X Tanpa Obat, Sindrom X: Diabetes Tipe-2, Hiperkolesterolemia, dan Hipertrigliserida, Hipertensi, dan Obesitas. Jakarta: PT Elex Media Komputindo.

Neki, N.S., Gupta, H., MEeena, R., Mani, T., 2015. A Study of Association of Hyperuricemia with Progressive Diabetec Nephropathy, JIMSA, 28(1): 13-19.

Martínez, Yolanda, V., Carlos, A. Prado-Aguilar, Ramón A Rascón-Pacheco and José J ValdiviaMartíne. 2008. Quality of life associated with treatment adherence in patients with type 2 diabetes: a cross-sectional study. BMC Health Services Research, 8:164.

Morisky, D.E., Ang, A., Krousel-Wood, M., Ward, H.J.. 2008. Predictive validity of a medication adherence measure in an outpatient setting. J Clin Hypertens (Greenwich), 10, 348-354.

Mulyani, R. 2016. Hubungan kepatuhan dengan keberhasilan terapi berbasis kombinasi insulin dan obat antidiabetik oral pada pasien diabetes mellitus tipe 2 diinstalasi rawat jalan rumah sakit umum daerah Ulin Banjarmasin. Prosiding Rakernas dan Pertemuan Ilmiah Tahunan Ikatan Apoteker Indonesia 2016.

Olenak, J.L.and Calpin, M., 2010. Establishing a cardiovascular health and wellness program in a community pharmacy: screening for metabolic syndrome. J Am Pharm Assoc, 50(1): 32-36.

Puspita, E. 2016. Faktor-faktor yang berhubungan dengan kepatuhan penderita hipertensi dalam menjalani pengobatan. Skripsi. Fakultas Ilmu keolahragaan, Jurusan Ilmu Kesehatan Masyarakat. Universitas Negeri Semarang. Semarang : Indonesia.

Putri, R.I., 2015. Faktor Determinan Nefropati Diabetik pada penderita Diabetes Mellitus di RSUD Dr. M. Soewandhie Surabaya. Jurnal Berkala Epidiomologi, 3(10): 109-121.

Rahma, A., Arso, S.P., Suparwati, A., 2015. Implementasi Fungsi Pokok Pelayanan Primer Puskesmas sebagai Gatekeeper dalam Program JKN (studi di Puskesmas Juwana Kabupaten Pati), jurnal kesehatan masyarakat (e-Journal), 3(3).

Ramadhan, M.R., 2014. Pengaruh ketepatan terapi dan kepatuhan terhadap hasil terapi hipertensi di poliklinik penyakit dalam RSUP Dr. Sardjito Yogyakarta. J. Trop. Pharm. Chem, 2(5).

Siregar, C., 2006. Farmasi klinik teori dan penerapan. Jakarta : EGC.

Sudjatmiko, A., 2011. Faktor-faktor yang berhubungan dengan kemunculan komplikasi kronik pada Penderita Diabetes Mellitus Tipe 2 RSUD Kabupaten Kududs. Skripsi. Semarang ; Fakultas Kesehatan Masyarakat Universitas Diponegoro.

Touchette, D., 2010. Improving adherence in the community and clinic pharmacy settings: an emerging opportunity. Pharmacotherapy, 30,425-427. 
Verdiansah, 2016. Pemeriksaan Fungsi Ginjal. CDK,237,43(2), 11-16

WHO. 2003. Adherence to Long-Term Therapies (Evidence for action). WHO Library Cataloguing-InPublication Data.

Wijaya, I. , Faturrohmah, A., Agustin, W.W., Soesanto, T.G., Kartika, D., 2015. Profil kepatuhan pasien diabetes mellitus Puskesmas Wilayah Surabaya Timur dalam menggunakan obat dengan metode pill count. Jurnal Farmasi Komunitas, 2(1), 18-22. 
